\title{
ANALISIS RANTAI NILAI KOMODITAS IKAN AIR TAWAR UNGGULAN DI KOTA TANGERANG
}

\author{
Mentari Argarini, Akhmad Riyadi Wastra* dan Rizki Adi Puspita Sari
}

\begin{abstract}
ABSTRAK
Penelitian ini digunakan untuk melihat kondisi rantai nilai komoditas ikan air tawar unggulan dalam rangka mencapai ketahanan pangan di Tangerang. Tujuan dari penelitian ini adalah 1) untuk menganalisis jenis benih ikan komoditas air tawar, 2) mengidentifikasi rantai pasokan komoditas benih ikan air tawar, 3) menganalisis, mengidentifikasi, dan memetakan rantai nilai komoditas benih ikan air tawar dan 4) menganalisis nilai tambah yang dihasilkan dari semua aktor yang terlibat dalam rantai komoditas ikan air tawar unggulan kami di Tangerang. Penelitian ini dilakukan di Kota Tangerang. analisis adalah MPE analisis, supply chain, rantai nilai dan nilai tambah metode Hayami. Komoditas ikan air tawar lele dengan fitur 155,130,122.9. rantai pasokan lele melibatkan empat pelaku, termasuk petani, pedagang, pedagang pasar tradisional dan pedagang ikan olahan. Kondisi rantai pasokan dan rantai nilai tidak efektif dan efisien, terutama pada petani karena produksi terbatas dan kesenjangan marjin. Memperoleh marjin terbesar dari olahan ikan merchant Rp 4.4892,05 / kg, sedangkan margin terkecil di petani Rp 152,22 / kg. Perhitungan nilai tambah sebesar Rp 5.532,96 / kg petani, pedagang Rp 2.368,23 / kg, pedagang pasar tradisional Rp 2.061,44 / kg dan diproses pedagang ikan Rp 3.578,16 / ikan, atau Rp 2.5047,12 / kg. Nilai terbesar tambah pedagang diperoleh olahan ikan, sedangkan nilai terkecil tambah yang diperoleh petani. Oleh karena itu, sebagai regulator dan fasilitator, pemerintah harus meningkatkan nilai tambah dan mengoptimalkan produksi perikanan di Tangerang.
\end{abstract}

Kata kunci: lele, metode perbandingan eksponensial, rantai pasokan, rantai nilai, nilai tambah

\begin{abstract}
This research is used to view the condition of the commodities value chain of freshwater fish featured in order to achieve food stability in Tangerang. The purpose of this study were 1) to analyze the type of commodity freshwater fish seed, 2) identify commodity supply chain of freshwater fish seed, 3) analyze, identify, and map the commodity value chain of freshwater fish seed and 4)
\end{abstract}


analyze the value added resulting from all actors involved in the chain of freshwater fish commodity featured in Tangerang. This research was conducted in the city of Tangerang. The analysis is the MPE analysis, supply chain, value chain and value added Hayami method. Commodities of freshwater fish are catfish featured with 155,130,122.9. Catfish supply chain involves four actors, including farmers, traders, traditional market traders and traders of processed fish. Conditions of supply chain and value chain has not been effective and efficient, especially on farmers due to limited production and margin gap. Obtained the largest margin of processed fish merchant IDR 4.4892,05/kg, while the smallest margin in farmers IDR 152,22/kg. Calculation of value added at IDR 5.532,96/kg farmers, traders IDR 2.368,23/kg, traditional market traders IDR 2061.44/kg and processed fish merchant IDR 3.578,16/fish, or IDR 2.5047,12/kg. The biggest value added obtained traders processed fish, whereas the smallest value added obtained by farmers. Therefore, as a regulator and facilitator, the government has to be increase the value added and optimize fisheries production in Tangerang.

Keywords: catfish, exponential comparison methode, supply chain, value chain, value added

\section{PENDAHULUAN}

Perikanan merupakan subsektor pertanian yang mempunyai peran penting sebagai salah satu penyedia sumber pangan hewani dan bahan baku industri. Hasil perikanan dapat mencukupi kebutuhan pangan, khususnya kebutuhan protein hewani. Protein hewani pada ikan sangat dibutuhkan untuk pertumbuhan anak, membantu mencerdaskan otak dan bagi kaum lanjut usia tidak berisiko terlalu tinggi terhadap kandungan lemaknya dibandingkan dengan sumber protein lainnya (Saparinto dan Susiana, 2013). Perikanan dapat dijadikan sarana penyerapan tenaga kerja dan mampu berkontribusi terhadap perekonomian nasional dan daerah.

Berdasarkan data Dinas Ketahanan Pangan dan Pertanian Kota Tangerang, produksi perikanan mengalami fluktuasi. Perubahan pola pikir masyarakat perkotaan merupakan fenomena yang terjadi saat ini, yaitu terjadinya alih profesi dimana masyarakat memilih pekerjaan praktis yang menghasilkan penghasilan tetap dan keuntungan besar dengan sedikit risiko. Hal tersebut mengakibatkan penurunan jumlah tenaga kerja di bidang pertanian sehingga berpengaruh terhadap jumlah produksi perikanan air tawar.

Produksi perikanan terbesar terjadi pada tahun 2012, yaitu 474,36 ton dengan nilai produksi sebesar $\mathrm{Rp}$ 6.543.630.000,00. Pada tahun 2013, subsektor perikanan mengalami penunuran jumlah produksi sebesar 12,44 ton dan mengalami kenaikan 10,14 ton pada tahun 2014 (Lampiran 1). Peningkatan produksi tersebut masih belum bisa memenuhi kebutuhan konsumsi ikan di Kota Tangerang yang mempunyai jumlah penduduk sebesar 1.952.396 jiwa (Data Statistik Kota Tangerang 2014). 
Tingkat konsumsi ikan di Kota Tangerang mengalami kenaikan setiap tahunnya, namun hanya menduduki peringkat kelima di Provinsi Banten, yaitu sebesar $24,65 \%$ pada tahun 2013. Rendahnya tingkat konsumsi ikan di Tangerang harus diatasi dengan serius. Salah satu cara yang dilakukan adalah melalui gerakan memasyarakatkan makan ikan (gemarikan). Pemerintah Kota Tangerang berupaya untuk meningkatkan produksi ikan melalui pengembangan budidaya ikan air tawar.

Letak geografi dan topografi Kota Tangerang merupakan faktor penentu keberhasilan pengembangan agribisnis perikanan. Pengembangan budidaya ikan air tawar konsumsi merupakan cara tepat dalam pemanfaatan lahan marjinal dan terbatas di Kota Tangerang, hal ini dikarenakan pesatnya laju pembangunan di lahan produktif dan tidak adanya wilayah perairan laut. Keterbatasan tersebut dijadikan sebuah peluang dalam mengembangkan potensi daerah dan cara untuk mengatasi penangkapan ikan secara berlebihan (over fishing) karena akan mengakibatkan kelangkaan spesies ikan di laut.

Jenis ikan air tawar konsumsi yang dapat dibudidayakan di Kota Tangerang antara lain ikan mas, lele, mujair, patin, gurami dan nila. Pemanfaatan agribisnis perikanan harus dilakukan secara terintegrasi dari hulu hingga hilir agar terbentuk nilai yang relatif sama di sepanjang rantainya. Kesenjangan yang terjadi diantara pelaku dalam mata rantai menandakan belum optimalnya kegiatan pengembangan budidaya ikan air tawar di Kota Tangerang.

Pemenuhan permintaan ikan air tawar yang berasal dari budidaya lokal bertujuan agar tidak terjadi peningkatan nilai yang lebih tinggi di tingkat konsumen karena semakin panjangnya rantai pasok. Pentingnya peran komoditas ikan air tawar dalam rangka optimalisasi pemanfaatan sumber daya yang ada melalui program minapolitan dalam skala kecil untuk meningkatan produksi pangan, maka relevan jika dilakukan penelitian mengenai analisis rantai nilai komoditas ikan air tawar unggulan di Kota Tangerang.

Tujuan dari penelitian ini, yaitu 1) menganalisis jenis komoditas ikan air tawar unggulan, 2) mengidentifikasi rantai pasok komoditas ikan air tawar unggulan, 3) menganalisis, mengidentifikasi, dan memetakan rantai nilai komoditas ikan air tawar unggulan dan 4) menganalisis nilai tambah yang dihasilkan dari setiap pelaku yang terlibat dalam mata rantai komoditas ikan air tawar unggulan di Kota Tangerang.

Penelitian ini dibatasi hanya pada mata rantai komoditas ikan air tawar unggulan di Kota Tangerang yang diperoleh dari pendapat para pakar, yaitu berdasarkan saluran rantai pasok dari mulai budidaya sampai dengan pemasaran produk olahan ikan kepada konsumen. Penelitian ini difokuskan untuk mengukur nilai tambah pada pelaku rantai nilai, yaitu pelaku budidaya ikan air tawar yang berada di kecamatan dengan tingkat produksi ikan air tawar unggulan terbesar di Kota Tangerang.

\section{METODE PENELITIAN}

Penelitian dilakukan selama lima bulan, yaitu dari bulan MaretJuli 2015. Penentuan sampel dilakukan dengan menggunakan 
purposive sampling dan snowball sampling. Purposive sampling digunakan untuk menentukan pakar dalam menganalisis jenis ikan air tawar unggulan dan petani ikan dengan tujuan mencari kecamatan yang memproduksi ikan air tawar, sedangkan snowball sampling digunakan untuk menentukan pelaku rantai nilai. Data yang digunakan dalam penelitian meliputi data primer dan sekunder. Data primer berupa wawancara secara mendalam dan pengisian kuesioner. Data sekunter terdiri dari dokumen atau catatan dari setiap pelaku dalam mata rantai, data penelitian terdahulu, studi pustaka berupa literatur yang relevan dengan masalah penelitian, serta situs internet.

Penelitian ini menggunakan metode deskriptif. Pengolahan dan analisis data dilakukan secara kualitatif dan kuantitatif dengan menggunakan analisis metode perbandingan eksponensial (MPE), rantai pasok, rantai nilai dan nilai tambah.

\section{Analisis metode perbandingan eksponensial (MPE)}

Analisis MPE menggunakan beberapa tahapan, yaitu menyusun alternatif keputusan, menentukan kriteria keputusan untuk dievaluasi, menentukan tingkat kepentingan dari setiap kriteria, melakukan penilaian terhadap semua alternatif, menghitung skor atau nilai total setiap alternatif dan menentukan urutan prioritas keputusan didasarkan pada skor atau nilai total masing-masing alternatif (Marimin, 2004).

Alternatif keputusan terdiri dari enam jenis ikan air tawar konsumsi yang terdapat di Kota Tangerang, yaitu ikan mas, lele, mujair, patin, gurami dan nila. Pemilihan alternatif keputusan tersebut berdasarkan data yang diperoleh dari Dinas Ketahanan Pangan dan Pertanian. Penentuan kriteria dalam penelitian ini berdasarkan studi pustaka dalam buku berjudul "Sukses Pembenihan 6 Ikan Air Tawar Ekonomis dan Bisnis Ikan Konsumsi di Lahan Sempit". Kriteria ditentukan sebanyak sepuluh kriteria, yaitu teknologi budidaya, permodalan terjangkau, risiko budidaya rendah, ketersediaan pakan, potensi lahan, daya serap pasar, kestabilan harga, nilai tambah komoditas ikan, kualitas komoditas ikan dan bantuan pemerintah.

\section{Analisis rantai pasok}

Analisis rantai pasok dilakukan secara kualitatif deskriptif, yaitu dengan menganalisis alur pasok ikan air tawar unggulan, mulai dari budidaya ikan air tawar unggulan sampai dengan pemasaran ikan segar atau olahan ikan kepada konsumen. Analisis ini digunakan untuk mengidentifikasi pelaku yang terlibat langsung dalam kegiatan rantai pasok ikan air tawar unggulan di Kota Tangerang yang terdiri dari petani, pedagang pengumpul, pedagang pasar tradisional dan pedagang olahan ikan.

3. Analisis rantai nilai

Analisis rantai nilai digunakan untuk mengetahui kondisi mata rantai komoditas ikan unggulan di Kota Tangerang. Hasil analisis diidentifikasi dan dipetakan sesuai dengan kondisi yang terjadi. Analisis rantai nilai ini mendeskripsikan aktivitas-aktivitas yang dilakukan di setiap rantai, baik aktivitas primer atau aktivitas pendukung. Rantai nilai merupaka cara sistematik untuk memeriksa semua aktivitas yang dilakukan oleh perusahaan dan bagaimana semua aktivitas itu 
berinteraksi untuk menganalisis sumber keunggulan bersaing (Porter, 1994).

\section{Analisis nilai tambah}

Konsep nilai tambah adalah suatu perubahan nilai yang terjadi karena adanya perlakuan terhadap suatu input pada suatu proses produksi (Marimin dan Maghfiroh, 2010). Analisis nilai tambah dilakukan secara kuantitatif dengan menggunakan metode Hayami dengan asumsi bahwa biaya investasi usaha tidak dimasukkan ke dalam perhitungan karena usaha sudah berjalan.

Tahapan yang dilakukan dalam penelitian ini, yaitu 1) mencari informasi mengenai komoditas ikan air tawar konsumsi yang bernilai ekonomis dan banyak dikembangkan di Kota Tangerang, 2) melakukan analisis kuantitatif dengan menggunakan metode perbandingan eksponensial (MPE) berdasarkan pendapat pakar, 3) mendeskripsikan hasil observasi dan wawancara dengan semua pelaku yang terlibat dalam mata rantai komoditas ikan air tawar unggulan untuk menganalisis rantai pasok dan rantai nilai dan 4) melakukan analisis nilai tambah untuk menganalisis besarnya nilai di setiap mata rantai. Hasil yang akan didapatkan adalah nilai di setiap mata rantai secara keseluruhan yang berimplikasi terhadap ketahanan pangan Kota Tangerang.

\section{HASIL DAN PEMBAHASAN}

\section{Pemilihan Ikan Air Tawar Unggulan}

Ikan air tawar unggulan diperoleh dari hasil analisis MPE melalui wawancara dan pengisian kuesioner oleh pakar. Pakar menentukan tujuh kriteria yang paling berpengaruh terhadap pengembangan komoditas ikan air tawar. Selanjutnya pemberian bobot pada masing-masing kriteria. Hasil pemilihan kriteria dan bobot dirata-ratakan sebagai acuan dalam perhitungan MPE. Berikut adalah hasil perhitungan rata-rata nilai MPE.

Tabel 1. Hasil Perhitungan MPE

\begin{tabular}{lcc}
\hline Prioritas & $\begin{array}{c}\text { Alternatif } \\
\text { Komoditas } \\
\text { Ikan Air } \\
\text { Tawar }\end{array}$ & $\begin{array}{c}\text { Nilai Rata- } \\
\text { rata MPE }\end{array}$ \\
\hline Komoditas & Lele & $155.130 .122,9$ \\
Potensial 1 & & \\
Komoditas & Gurami & $89.741 .409,8$ \\
Potensial 2 & & $80.685 .288,0$ \\
Komoditas & Nila & \\
Potensial 3 & & $68.572 .222,2$ \\
Komoditas & Mujair \\
Potensial 4 & & $68.366 .699,2$ \\
Komoditas & Mas & \\
Potensial 5 & & $62.463 .470,1$ \\
Komoditas & Patin & \\
Potensial 6 & & \\
\hline
\end{tabular}

Sumber: Data Primer Diolah (2015)

Hasil perhitungan MPE, komoditas potensial 1 adalah ikan lele dengan rata-rata nilai sebesar 155.130.122,9. Komoditas potensial 2 adalah ikan gurami dengan nilai $89.741 .409,8$. Urutan ketiga diduduki oleh ikan nila sebagai komoditas potensial 3 dengan nilai 80.685.28. Komoditas potensial 4 adalah ikan mujair dan komoditas potensial 5 adalah ikan mas dengan nilai masingmasing sebesar 68.572.222,2 dan 68.366.699,2. Urutan terakhir komoditas potensial adalah ikan patin, yaitu sebesar 62.463.470,1. 
Ikan lele menjadi pilihan prioritas utama karena mempunyai keunggulan dibandingkan dengan kelima ikan air tawar lainnya. Ikan lele merupakan komoditas ikan air tawar yang dapat hidup dan beradaptasi di semua jenis lingkungan. Ikan lele yang banyak dikembangkan di Kota Tangerang adalah ikan lele dumbo (Clarias gariepinus). Teknologi budidaya Ikan lele cukup sederhana, sehingga mudah dilakukan. Budidaya Ikan lele dapat dilakukan di lahan terbatas dengan menggunakan kolam terpal. Pakan ikan lele banyak tersedia di sekitar lingkungan tempat budidaya, baik pakan alami maupun buatan. Selain itu, daya serap pasar Ikan lele sangat tinggi, hal tersebut dikarenakan banyaknya permintaan ikan lele di pasaran. Pemerintah Kota Tangerang mempunyai anggaran dalam mengembangkan budidaya ikan lele dengan memberikan bantuan permodala berupa bibit ikan lele.

\section{Rantai Pasok Ikan Lele}

Saluran rantai pasok ikan lele di enam kecamatan di Kota Tangerang, yaitu Kecamatan Periuk, Pinang,
Cipondoh, Neglasari, Karawaci dan Benda, terdiri dari petani, pedagang pengumpul, pedagang pasar tradisional dan pedagang olahan ikan. Saluran rantai pasok ikan lele di Kota Tangerang seperti yang terdapat dalam teori rantai pasok yang dikemukakan oleh Marimin dan Maghfiroh (2010), yaitu manajemen rantai pasok produk pertanian mewakili manajemen keseluruhan proses produksi secara keseluruhan dari kegiatan pengolahan, distribusi, pemasaran, hingga produk yang diinginkan sampai ke tangan konsumen.

Berdasarkan hasil penelitian, sebagian besar petani lele masih melakukan penjualan ikan lele kepada pedagang pengumpul. Hal tersebut dikarenakan petani yang tidak ingin disulitkan dalam pengiriman dan penjualan ikan kepada konsumen. Pada lokasi budidaya, petani tidak melakukan penyortiran ikan. Semua ikan lele yang siap panen secara fisik langsung dibeli oleh pedagang pengumpul dengan harga yang telah disepakati bersama. Saluran rantai pasok dapat dilihat pada Gambar 1.

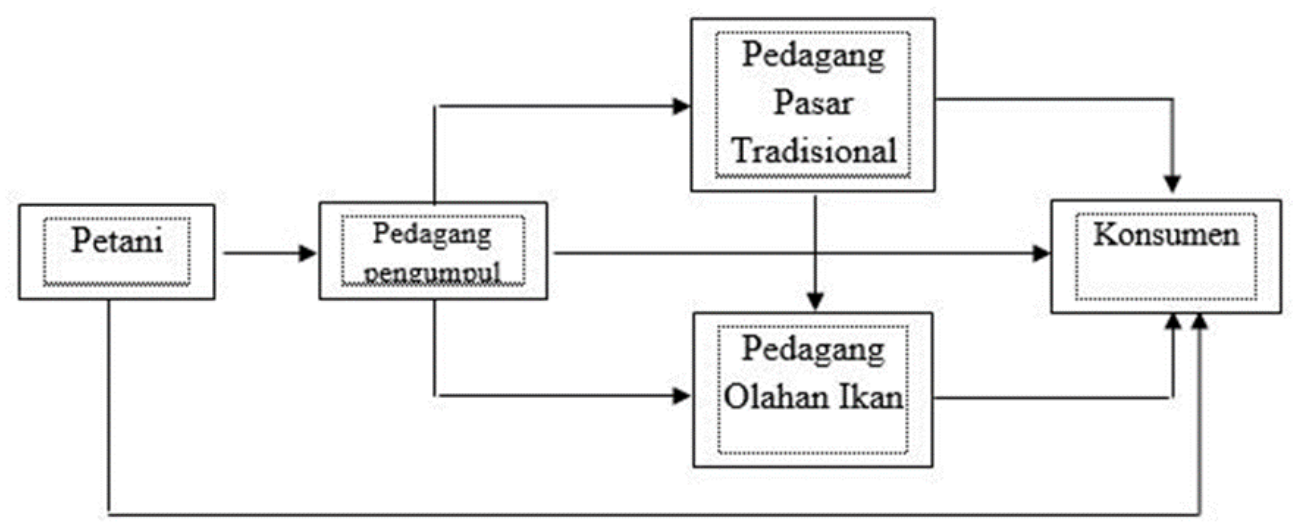

Gambar 1. Rantai Pasok Ikan Lele di Kota Tangerang 
Hasil penelitian menunjukkan bahwa saluran rantai pasok yang paling efektif adalah saluran pertama karena petani memperoleh keuntungan usaha yang lebih tinggi, namun saluran ini tidak efisien karena jumlah konsumen yang terbatas dan memerlukan promosi penjualan yang lebih luas. Saluran rantai pasok yang panjang akan menambah nilai di tingkat konsumen. Terbatasnya jumlah produksi ikan lele hasil produksi petani di Kota Tangerang dapat menghambat ketersediaan pasokan lele di Kota Tangerang dan akan mempengaruhi nilai di setiap pelaku rantai pasok.

\section{Rantai Nilai Ikan Lele}

Rantai nilai berkaitan dengan keunggulan bersaing suatu perusahaan. Keunggulan bersaing berasal dari banyak aktivitas berlainan yang dilakukan oleh perusahaan dalam mendesain, memproduksi, memasarkan, menyerahkan, dan mendukung produknya (Porter, 1994). Aktivitas utama dalam rantai nilai ikan lele adalah proses produksi ikan lele, dimulai dari pemijahan, pembesaran, pemberian pakan, pemeliharaan, panen dan pasacapanen. Aktivitas pendukung langsung yang dilakukan adalah penyuluhan dan pelatihan, sedangkan aktivitas tidak langsung mencakup bantuan pemerintah, baik permodalan fisik atau materi.

Pemetaan rantai nilai ikan lele bertujuan untuk melihat peran dari masing-masing pelaku yang terlibat dalam mata rantai. Menurut Kaplinsky dan Morris dalam Australian Center for International Agricultural Research (2012:12), aspek pertama yang dilakukan di tingkat paling dasar suatu analisis rantai nilai secara sistematis adalah memetakan para pelaku yang berpartisipasi dalam produksi, distribusi, pemasaran, dan penjualan suatu produk tertentu.

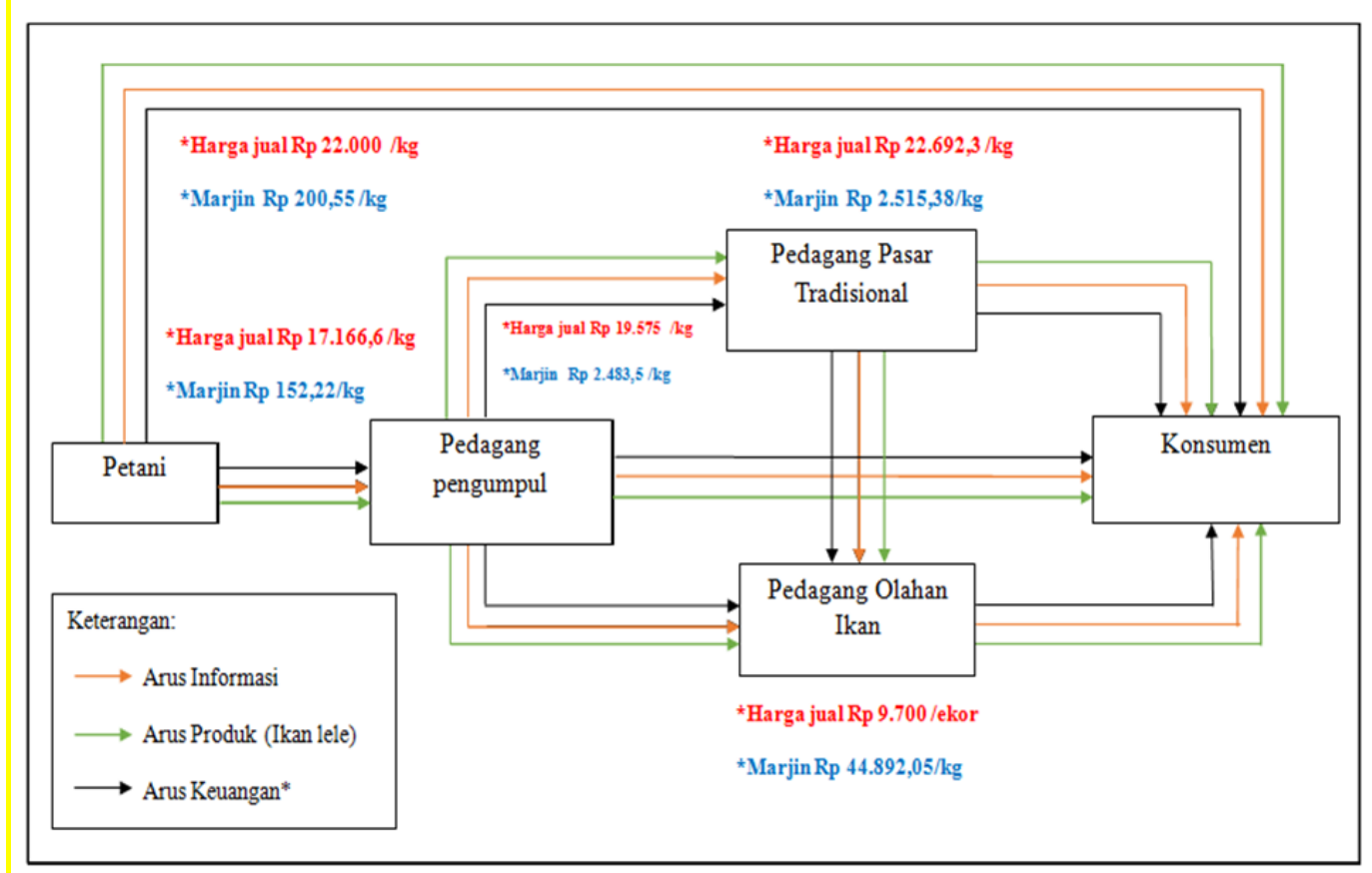

Sumber: Data Primer Diolah (2015)

Gambar 2. Rantai Nilai Ikan Lele di Kota Tangerang 
Pelaku rantai nilai terdiri dari petani, pedagang pengumpul, pedagang pasar tradisional dan pedagang olahan ikan.

\section{Petani}

Petani berasal dari enam kecamatan, yaitu Kecamatan Pinang, Cipondoh, Benda, Karawaci, Neglasari dan Kecamatan Periuk. Petani memanfaatkan lahan tidur atau tidak terpakai dan pekarangan rumah sebagai lahan budidaya. Petani di Kota Tangerang hanya mampu memproduksi ikan lele rata-rata sebesar 500 kilogram dan tidak mencukupi permintaan ikan lele. Harga jual ikan lele di tingkat petani untuk penjualan partai besar sebesar $\mathrm{Rp} \quad 15.000,00-\mathrm{Rp} \quad 17.000,00$, sedangkan untuk konsumen adalah Rp 21.000,00-Rp 22.000,00. Harga rata-rata ikan lele di tingkat petani adalah Rp 17.166,6 per kilogram. Petani hanya memperoleh marjin sebesar Rp 152,22 per kilogram per hari atau setara dengan $\mathrm{Rp} \mathrm{13.699,94}$ per kilogram dalam waktu tiga bulan. Sedangkan marjin yang diperoleh petani yang menjual ikan lele langsung kepada konsumen adalah sebesar Rp 200,55 per kilogram per hari atau setara dengan $\mathrm{Rp} \mathrm{18.050,00}$ per kilogram dalam waktu tiga bulan.

\section{Pedagang pengumpul}

Pedagang pengumpul berjumlah

4 orang dengan sistem penjualan adalah membeli langsung dari petani ikan lele. Kendala yang dialami oleh pedagang pengumpul adalah kesulitan mencari ikan lele produksi Kota Tangerang karena keterbatasan jumlah produksi. Hasil penelitian menunjukkan bahwa pedagang pengumpul memperoleh marjin sebesar Rp 2.483,5 per kilogram dengan harga jual rata-rata $\mathrm{Rp} 19.575$ per kilogram.

3. Pedagang pasar tradisional

Pedagang pasar tradisional berjumlah 13 orang. Konsumen yang membeli ikan dari pedagang pasar adalah pedagang pecel lele, warung tegal, warung padang dan ibu rumah tangga. Ikan lele dijual secara hidup dan tidak memerlukan wadah luas dan air mengalir. Pedagang mendapatkan ikan lele yang dikirim langsung oleh pedagang pengumpul. Pedagang menjual kembali ikan lele dengan harga rata-rata sebesar $\mathrm{Rp}$ 22.692,3 per kilogram. Marjin yang diperoleh pedagang pasar adalah $\mathrm{Rp}$ $2.515,38$ per kilogram.

4. Pedagang olahan lele

Pedagang olahan lele yang dipilih dalam penelitian ini adalah pedagang pecel lele karena merupakan pembeli ikan lele dalam jumlah yang paling banyak, yaitu sekitar 5-10 kilogram dengan jumlah 7-8 ekor/kilogram. Pedagang pecel lele banyak tersebar di Kota Tangerang karena tidak memerlukan keterampilan khusus untuk pengolahan dan menghasilkan keuntungan. Aktivitas keempat pelaku tersebut belum berjalan dengan baik. Adanya permasalahan pada salah satu pelaku akan mempengaruhi nilai dan ketersediaan ikan lele di Kota Tangerang. Pedagang pecel lele memperoleh marjin sebesar Rp 6.413,15 per ekor. Marjin yang diperoleh dalam 1 kilogram pecel lele adalah $\mathrm{Rp}$ 44.892,05.

Secara keseluruhan, rantai nilai komoditas ikan lele belum berjalan dengan baik. Hasil penelitian menunjukkan bahwa marjin terendah diperoleh oleh petani, sedangkan 
marjin tertinggi diperoleh oleh pedagang olahan ikan. Petani tidak bisa menciptakan nilai karena tidak mempunyai posisi tawar. Pemanfaatan kelompok tani harus dilakukan secara optimal sebagai sarana perbaikan sistem usaha budidaya dengan cara merubah pola produksi dan pemasaran. Rantai nilai sangat berkaitan dengan rantai pasok. Rantai nilai terputus pada saat petani tidak dapat memasok ikan lele kepada pedagang pengumpul, sehingga ikan lele yang beredar di pasaran Kota Tangerang adalah lele yang berasal dari luar wilayah. Lele hasil produksi petani yang terdapat di Kota Tangerang belum tersebar secara merata. Peningkatan nilai di tingkat petani harus dilakukan untuk mendorong petani meningkatkan produksi ikan lele dalam rangka mewujudkan ketahanan pangan

\section{Nilai Tambah Ikan Lele}

Produksi ikan lele di Kota Tangerang belum ditangani secara tepat melalui proses pengolahan. Pelaku rantai nilai tidak melakukan pengolahan ikan menjadi produk atau panganan dalam kemasan karena beberapa alasan, antara lain 1) ketidaktertarikan terhadap produk olahan ikan lele, 2) kurangnya keterampilan sumber daya manusia dalam pengolahan hasil perikanan budidaya, 3) dukungan pemerintah, seperti penyuluhan pengolahan pascapanen ikan lele belum dilakukan secara merata, 4) tidak adanya sumber permodalan, 5) membutuhkan teknologi yang tidak sederhana dan waktu produksi yang relatif lebih lama dan 6) pemasaran hasil olahan yang lebih sulit karena belum adanya pasar terhadap produk olahan ikan lele dalam bentuk frozen food atau produk kemasan.

\section{Implikasi Rantai Nilai}

Pemerintah Kota Tangerang mempunyai peran yang sangat penting dalam pengelolaan rantai nilai ikan lele untuk mewujudkan ketahanan pangan daerah. Lembaga pemerintah yang berwenang adalah Dinas Ketahanan Pangan dan Pertanian Kota Tangerang.

Sebagai regulator, pemerintah berwenang dalam pengambilan kebijakan untuk pengelolaan agribisnis perikanan.

Kebijakan tersebut meliputi penetapan kawasan perikanan atau minapolitan dalam skala kecil, budidaya perikanan, bantuan permodalan, dan peningkatan nilai tambah hasil perikanan. Sebagai fasilitator, pemerintah harus menyediakan fasilitas yang mendukung terlaksananya kebijakan tersebut. Namun, kebijakan-kebijakan tersebut belum berjalan dengan baik.

Penerapan kawasan minapolitan dalam skala kecil dilakukan karena rendahnya tingkat produksi ikan lele di Kota Tangerang. Pemerintah memfokuskan, mengarahkan, dan mengawasi produksi perikanan di Kota Tangerang pada kawasan perikanan tersebut, yaitu di Kecamatan Periuk, Cipondoh, dan Pinang. Fokus utama pemerintah adalah budidaya ikan lele secara intensif melalui pembinaan petani dalam kelompok tani untuk meningkatkan produksi agar mampu mencukupi permintaan ikan lele di Kota Tangerang.

Kebijakan pemberian modal berupa bibit ikan lele belum dilakukan secara merata kepada semua petani di Kota Tangerang. Pemerintah tidak memberikan bantuan finansial kepada petani. Saat 
ini, bantuan berupa bibit lele hanya diberikan kepada petani yang tergabung dalam kelompok tani, yaitu sebesar 5.000 ekor benih dan 50 kilogram pakan pada awal tahun.

Dinas Ketahanan Pangan dan Pertanian harus menjadi penghubung antara petani dengan usaha pengolahan ikan melalui kerjasama, yaitu petani sebagai pemasok bahan baku ikan lele dan pelaku usaha memberikan pelatihan dalam pengolahan ikan. Pemerintah memfasilitasi petani dan pelaku usaha dalam permohonan PIRT. Keterlibatan petani akan meningkatkan nilai tambah dan marjin penerimaan yang lebih tinggi. Kondisi tersebut dapat berdampak positif bagi Kota Tangerang, yaitu terwujudnya ketahanan pangan dengan melihat rantai nilai yang terbentuk dan adanya peran pemerintah dalam mendukung optimalisasi produksi perikanan.

\begin{tabular}{|c|c|c|c|c|}
\hline Variabel & $\begin{array}{l}\text { Petani } \\
(\text { Rp/kg) }\end{array}$ & $\begin{array}{c}\text { Pedagang } \\
\text { pengumpul } \\
(\mathrm{Rp} / \mathrm{kg})\end{array}$ & $\begin{array}{c}\text { Pedagang } \\
\text { pasar } \\
(\mathrm{Rp} / \mathrm{kg})\end{array}$ & $\begin{array}{c}\text { Pedagang } \\
\text { olahan ikan } \\
\text { (Rp/ekor) }\end{array}$ \\
\hline Output $(\mathrm{Kg})$ & 417 & 334,12 & 122,56 & 51 \\
\hline Input $(\mathrm{Kg})$ & 463,33 & 337,5 & 123,8 & 52 \\
\hline Tenaga kerja langsung (HOK) & 5,46 & 3,5 & 8,4 & 7,85 \\
\hline Faktor konversi & 0,90 & 0,98 & 0,98 & 0,98 \\
\hline $\begin{array}{l}\text { Koefisien tenaga kerja langsung } \\
(\mathrm{HOK} / \mathrm{Kg})\end{array}$ & 0,01 & 0,01 & 0,06 & 0,15 \\
\hline Harga output (Rp/Kg) & $17.166,6$ & 19.575 & $22.692,30$ & 9.700 \\
\hline $\begin{array}{l}\text { Upah tenaga kerja langsung } \\
\text { (Rp/HOK) }\end{array}$ & $47.343,75$ & 50.000 & $30.740,74$ & $21.904,76$ \\
\hline Harga bahan baku (Rp/Kg) & 1.750 & 16.700 & $19.723,07$ & $3.092,85$ \\
\hline Harga input lain (Rp/Kg) & $8.166,98$ & 115,27 & 453,94 & $2.834,99$ \\
\hline Nilai output (Rp/Kg) & $15.449,94$ & $19.183,5$ & $22.238,45$ & 9.506 \\
\hline a. Nilai tambah $(\mathrm{Rp} / \mathrm{Kg})$ & 5.532 & $2.368,23$ & $2.061,44$ & $3.578,16$ \\
\hline b. Rasio nilai tambah (\%) & 35,81 & 12,34 & 9,26 & 37,64 \\
\hline a. Pendapatan tenaga kerja & 473,43 & 500 & $1.844,44$ & $3.285,71$ \\
\hline $\begin{array}{l}\text { langsung }(\mathrm{Rp} / \mathrm{Kg}) \\
\text { b. Pangsa tenaga kerja langsung } \\
(\%)\end{array}$ & 8,55 & 21,11 & 91,41 & 91,82 \\
\hline a. Keuntungan $(\mathrm{Rp} / \mathrm{Kg})$ & $5.059,57$ & $1.868,23$ & 217 & 292,45 \\
\hline b. Tingkat keuntungan (\%) & 32,74 & 9,73 & 0,97 & 3,07 \\
\hline Marjin $(\mathrm{Rp} / \mathrm{Kg})$ & $13.699,04$ & $2.483,5$ & $2.515,38$ & $6.413,15$ \\
\hline a. Pendapatan tenaga kerja & 3,45 & 20,13 & 73,32 & 51,23 \\
\hline langsung $(\%)$ & 59,61 & 4,64 & 18,04 & 44,20 \\
\hline $\begin{array}{ll}\text { b. } & \text { Sumbangan input lain }(\%) \\
\text { c. } & \text { Keuntungan perusahaan }(\%)\end{array}$ & 36,93 & 75,22 & 8,62 & 4,56 \\
\hline
\end{tabular}

Tabel 2. Hasil Perhitungan Nilai Tambah

\section{KESIMPULAN DAN SARAN}

\section{Kesimpulan}

Hasil perhitungan MPE diperoleh komoditas ikan air tawar 
unggulan, yaitu ikan lele dengan nilai tertinggi sebesar 155.130.122,9.

1. Rantai pasok ikan lele melibatkan empat pelaku, yaitu petani, pedagang pengumpul, pedagang pasar tradisional dan pedagang olahan ikan.

2. Kondisi rantai pasok dan sistem pemasaran belum berjalan secara efektif dan efisien, terutama pada tingkat petani karena keterbatasan produksi ikan lele yang menyebabkan terputusnya rantai pasok ikan lele hasil produksi petani di Kota Tangerang dan menandakan belum berhasilnya program ketahanan pangan Kota Tangerang.

3. Secara umum, rantai nilai belum berjalan dengan baik karena adanya kesenjangan marjin penerimaan, yaitu pada petani.

4. Marjin terbesar dihasilkan pada pedagang olahan ikan, sedangkan marjin terkecil pada petani. Marjin yang diperoleh setiap pelaku adalah Rp 152,22 per kilogram pada petani, Rp $2.483,5$ per kilogram pedagang pengumpul, $\mathrm{Rp} 2.515,38$ per kilogram pedagang pasar tradisional dan Rp 44.892,05 per kilogram pada pedagang olahan ikan lele.

5. Hasil analisis dan perhitungan nilai tambah di tingkat petani sebesar Rp 5.532,96 per kilogram selama 3 bulan atau setara dengan $\mathrm{Rp} 61,47$ per kilogram per hari, pedagang pengumpul sebesar Rp 2.368,23 per kilogram, pedagang pasar tradisional sebesar Rp 2.061,44 per kilogram dan pedagang olahan ikan sebesar Rp 3.578,16 per ekor atau $\operatorname{Rp} 25.047,12$ per kilogram. Nilai tambah terbesar diperoleh pedagang olahan ikan, sedangkan nilai tambah terkecil diperoleh petani.

\section{Saran}

Penerapan agribisnis perikanan yang terintegrasi perlu dilakukan, yaitu dari hulu sampai hilir. Diperlukan komitmen semua pihak yang terlibat dalam rantai nilai ikan lele secara konsisten, terutama keterlibatan pemerintah Kota Tangerang dalam mengoptimalkan produksi perikanan budidaya untuk memenuhi permintaan ikan lele dalam rangka mewujudkan ketahanan pangan daerah. Pelaksanaan kegiatan rantai pasok ikan lele memerlukan pengelolaan manajemen yang baik untuk meminimalisir kekurangan pasokan ikan lele dan risiko yang akan terjadi, terutama risiko kematian ikan lele akibat kurang tepatnya penanganan pascapanen. Perlu diadakan pengawasan dan pengelolaan sumber daya yang terlibat dalam rantai nilai, yaitu dengan cara meningkatkan daya saing ikan lele untuk menaikkan harga jual ikan di tingkat petani agar tidak terjadi kesenjangan nilai yang semakin tinggi. Pengolahan ikan lele menjadi beragam produk panganan, baik produk setengah jadi, seperti frozen food atau siap saji, seperti abon ikan lele perlu dilakukan untuk meningkatkan nilai tambah, terutama pada tingkat petani. Perlu diadakan pemberdayaan keluarga petani berupa penyuluhan dan pelatihan pembuatan produk olahan ikan. 


\section{DAFTAR PUSTAKA}

Anonimous. 2013. Peraturan Daerah Kota Tangerang Nomor 10 Tahun 2014 Tentang Rencana Pembanguan Jangka Menengah Daerah Kota Tangerang Tahun 2014-2018.

Anonimous. 2013. Sekretariat Jenderal Kementerian Kelautan dan Perikanan. 2013. Pengembangan Program Minapolitan.

http://roren.kkp.go.id/index.ph p/arsip /file/71/preview-finalminapolitan.pdf/. [Diakses pada 18 April 2015].

Anonimous 2014. Badan Pusat Statistik Provinsi Banten. Katalog BPS: 1101002.36 Banten dalam Angka 2014.

Anonimous. 2014. Dinas Kelautan dan Perikanan Provinsi Banten.Tingkat Konsumsi Ikan Provinsi

Banten.http://www.dkp.banten prov.go.id/read /articledetail/pegumuman/109/ Tingkat-Konsumsi-IkanProvinsiBanten. html.[Diakses pada 15 April 2015].

Australian Center for International Agricultural Research. 2012. Membuat Rantai Nilai Lebih Berpihak pada Kaum Miskin. http://aciar.gov.au. [Diakses pada 9 April 2015].
Marimin. 2004. Teknik dan Aplikasi Pengembilan Keputusan Kriteria Majemuk. Jakarta: Grasindo.

Marimin dan Maghfiroh, Nurul. 2010. Aplikasi Teknik Pengambilan Keputusan dalam Manajemen Rantai Pasok. Bogor: PT. Penerbit IPB Press.

Narakusuma, M.A, Fauzi, A.M, Firdaus, M. Rantai Nilai Produk Olahan Buah Manggis. Jurnal Manajemen \& Agribisnis, Vol. 10 No. 1, Maret 2013.

Porter, Michael E. 1994. Keunggulan Bersaing Menciptakan dan Mempertahankan Kinerja Unggul. Jakarta: Binarupa Aksara.

Saparinto, Cahyo. 2014. Bisnis Ikan Konsumsi di Lahan Sempit. Jakarta: Penebar Swadaya.

Saparinto, Cahyo dan Susiana, Rini. 2013. Sukses Pembenihan 6 Jenis Ikan Air Tawar Ekonomis. Yogyakarta: ANDI.

Setiawati, Nur. 2014. Analisis Rantai Nilai Cabai di Sentra Produksi Kabupaten Majalengka Jawa Barat. [Tesis]. Sekolah Pascasarjana, Institut Pertanian Bogor.

* Alamat Koresponden :

riyadi.wastra@uinjkt.ac.id 
